\title{
Forced to deal with the future: uncertainty and risk in vocational choices among Portuguese secondary school students
}

\author{
Maria Manuel Vieira, Lia Pappámikail and \\ José Resende
}

\begin{abstract}
In contemporary societies, adolescents' individuation is largely staged within the educational system, and is defined by several schooling options. This is particularly true when young people reach upper secondary education, as this transition implies the definition of a personal project. In the Portuguese context, authenticity is linked to the 'obligation' of choosing - by means of a compulsory vocational choice. To define a personal project that gives studies a meaning becomes a problem pupils have to deal with. Supported on empirical data based on in-depth interviews to pupils attending 10th and 12th years of upper secondary education in Portuguese public schools, this article discusses some of these issues. Specially, we intend to explore pupils' obligation to exhibit their autonomy by choosing a school path with the awareness of risks that may emerge along with their options.
\end{abstract}

Keywords: adolescence, individuation, risk, secondary education, uncertainty, vocational choices

\section{Introduction}

The obligation to attend school for increasing periods of time, which has transformed schooling into a crucial part of a young person's biography, underlines the importance of the institutional settings in which life trajectories unfold. This is particularly true in Portugal, a country with traditionally poor attendance rates. ${ }^{1}$ Nowadays, however, when compared with the adult population, Portuguese adolescents have completed at least 9 years of study and the majority of those aged 15-17 (over 71 per cent in 2010) have carried on into upper secondary education. This represents not only a huge generational gap in terms of educational experience but also a profound change of potential for possibilities in their future lives.

It could thus be said that at present adolescent individuation (Breviglieri, 2007) takes place largely within the education system and is defined through various schooling options at the entry point to upper secondary education, as by John Wiley \& Sons Ltd., 9600 Garsington Road, Oxford OX4 2DQ, UK and 350 Main Street, Malden, 02148, USA. 
this transition implies, in the Portuguese context at least, the definition of a personal project. In fact, in contrast with the broad, generalist and almost universal logic that underlies the Portuguese basic education curriculum, secondary education is based on knowledge specialization. On entry to the secondary level (the 10th year of study, equivalent to upper secondary in other systems), pupils have to choose a more focused educational path from a diverse range of options: one of the four courses offered by the general education system (the more academic 'science and humanities courses') or one of the many courses offered by the technical and vocational education system (the work-related 'technical courses' and 'professional courses').

This means that the still-developing autonomous identity (of the adolescent) is challenged by the 'obligation' to choose a future destiny - by means of a compulsory vocational choice. Defining a personal project that gives a sense of purpose to what is being studied is therefore one of the main problems that secondary education pupils have to deal with.

This article aims to discuss this issue and propose a different theoretical perspective for the reinterpretation of the relationship between school vocational choices and the task of building a life project that every adolescent is compelled to perform. In particular, we intend to contrast the students' obligation to exhibit their autonomy by choosing a school 'pathway', on the one hand, and their awareness of the doubts and uncertainties that may emerge with their options, on the other, in order to examine the solutions they mobilize to cope with the situation.

The issue of how young people regard and deal with the future in times of increased uncertainties has been a conspicuous topic in youth studies research for at least two decades, and the object of intense debate (Pais, 2003; Brannen and Nilsen, 2002, 2005, 2007; Devadson, 2008; Leccardi, 2006, 2008; Woodman, 2009, 2011; Roberts, 2010). The fact is, however, that most of the researchers' analytical focus has been on the overall representations of young people with regard to their future lives as 'adults'. We propose, on the contrary, to concentrate on and closely examine how the 'future' is (or is not) brought into a particular life decision taken at a rather early stage in life.

In the first part of the article, we will briefly discuss some of the core concepts linked to the process of individuation through schooling. Following a brief explanation regarding the methodology used, the third part is dedicated to the analysis and discussion of students' accounts of their schooling trajectories, that is, it uses their justifications and explanations for the twists and turns they may have experienced along the way. Our argument unfolds in two sections. In the first, we explore the relationship between the construction processes of a vocational pathway and the relevance of authenticity as a structuring norm underlying the students' accounts of their school trajectories. In the second section, we examine the ways in which pupils deal with the uncertainties experienced and the risks perceived for their present and future. Special attention is given to the fact that adolescence tends to be a period when present experiences based on exploration and risk taking prevail over 
plans for the more distant future (Le Breton, 2008). Lastly, in the conclusions we summarize some of the most important results achieved.

\section{Vocational choices in upper secondary education: an adolescent dilemma?}

\section{Autonomy, uncertainty and risk}

In contemporary societies - which are structured by increased differentiation, the plurality of life worlds and the weakening of prescribed social roles individuation, or the process of constructing a biographical singularity (Beck, 1992; Martuccelli, 2010), is an experience that is as fundamental as it is problematic. Indeed, as the debate over how young people deal with the future has shown, we are far from the scenario of the full re-draw of social structures that some have predicted in contemporary Western societies (for example, Woodman, 2009, 2011).

According to some authors (Martuccelli, 2006; Breviglieri, 2007), individuation is carried out in a succession of tests and trials in which the choices made and decisions taken have definite implications, within a greatly amplified space of freedom. Trials, as Martuccelli (2006: 10) defines them, 'are a diverse set of historical challenges, socially produced and unequally distributed, that the individuals are constrained to deal with along their life course. They are the result of structural and institutional constraints, although diverse, according to social trajectories and positions'. That means that trials 'involve a conception of the individual as an actor who has to deal with the problems posed by social life' (Martuccelli, 2006: 11).

Although in each and every society individuals have to deal with a considerable number of trials, in contemporary societies the trials themselves become part of the perception of an individual's own life (Martuccelli, 2006). This is partly due to the increasingly institutionalized character that an individual's life course has acquired - biographical patterns are shaped by institutions (educational, occupational and social protection systems) (Heinz and Kruger, 2001; Heinz and Marshall, 2003; Sapin et al., 2007), which confront individuals with public tests (abilities, performances, qualities) in order to obtain social recognition, as Honneth (1995) has successfully argued.

At the same time, individuation implies the exercise of autonomy. As the values of individualism intensify in contemporary societies, autonomy, defined as self-governance, becomes not only a normative goal but also a process that individuals are invited/compelled to experience (Bauman, 2001, 2007; Pappámikail, 2009). In the ethical landscape of modernity, the greater freedom of circulation and action within and between plural social spheres explains the importance of practising, in order to prove competence in self-determination. But this process may entail certain ambiguities.

Exercising individual autonomy by choosing between multiple options (lifestyles, identities, social ties) may carry with it the perception of risk and 
the experience of uncertainty. Although social life has always been subject to potential risks and hazards (both natural and social), modernity has brought along an awareness of virtual risks due to the global - although unequally distributed - spread of knowledge and expertise (Beck, 1992; Beck and Beck-Gernsheim, 2001; Beck et al., 1994; Giddens, 1991). The perception of risk may inspire forms of anticipation or 'colonization' of the future (Giddens, 1991:242), entailing 'the creation of territories of future possibilities, reclaimed by counterfactual inference'. Furthermore, the ability to perceive, anticipate and deal biographically with virtual risk, by mobilizing information and/or experts, becomes itself a vital skill (Beck, 1992) - and ultimately a source of inequality - as it prevents uncontrolled and vulnerable situations.

Even so, exercising autonomy frequently confronts individuals with the experience of uncertainty and anxiety, which may be seen as a major consequence of living in a world that is presented to individuals as consisting of multiple choices (Bauman, 2007; Leccardi, 2006). This is particularly true when it comes to 'fateful moments'; in other words, moments 'where individuals are called on to take decisions that are particularly consequential for their ambitions, or more generally for their future life' (Giddens, 1991: 112). As they are irreversible 'points of transition' with a special impact on the individual's future, the feeling emerges of being trapped at a crossroads, along with uncertainties about the 'right' decision to make.

If the temporality (of life events) is of the utmost importance, contexts (the social times and spaces where trajectories unfold) are no less crucial to an understanding of biographies. According to Elder et al. (2003) these are indeed two of the five fundamental analytical principles of the life course paradigm. Actually, these particularly intense moments underline the importance of family and social networks, means of support, and available resources in the process of coping with uncertainty. In fact, the amount and quality of the resources that individuals have at their disposal (particularly economic, cultural and informational resources) constitute a crucial means of softening the impact of uncertainty and ensuring some degree of assurance when they have to choose - although the degree to which the individual seizes each and every resource and opportunity available may contribute considerably to his or her management of such social constraints (Thomson et al., 2002; Holland and Thomson, 2009; Lahire, 1998; Martuccelli, 2006; Threadgold and Nilan, 2009).

\section{Individuation through schooling and adolescence}

In general, the period following childhood is a time of undeniable physical and psychological transformation. Adolescents engage in an overall process of opening up to the world and widening their field of experience; through experimentation and exploration, they play the game of identity and belongings and adopt (new and different) behaviours that symbolically moves them away from childhood (Breviglieri, 2007). This translates into an increasing 
detachment from the close and familiar (known) world where childhood has been spent - and organized by significant adults.

The conquering of wider spheres of (a desired) freedom, which allows them to explore new and unknown social spaces, confronts adolescents with the need to be supported by new companions for the journey and to observe new rules - peers thus becoming the centre of gravity for young people's action. Accordingly, during adolescence, young people expose themselves and are exposed to more challenges in the public sphere. And, due to adolescent inexperience, this process predictably generates feelings of uncertainty and may provoke hesitation and doubt (Breviglieri, 2007), as individuals have to deal with the hard and complex task of building up their 'self' and their future.

On the other hand, as previously stated, the biographical patterns in modern societies are largely anchored in institutional contexts and the transitions within and between more or less institutionally defined pathways have been studied abundantly within the life course paradigm (Heinz and Kruger, 2001; Heinz and Marshall, 2003; Elder et al., 2003; Sapin et al., 2007). Moreover, youth studies have long been discussing the transitions into so-called 'adult life' in contemporary societies, examining the new patterns of life course calendars, the cadences and timings of transitions between school and the labour market, the life of the couple, and parenthood in various contexts. This has allowed them to relate life course and transition patterns to welfare state settings, social positions and cultural attitudes. They have done so independently of the theoretical tools used to interpret those changing patterns (Furlong and Cartmel, 1997; Arnett, 2004; Biggart and Walther, 2006; Pais and Ferreira, 2010, among others). Another research concern is how these specific transitions are experienced and combined into individual life narratives (relating to the past, present and projected futures). It has provided interesting insights into the ways individuals talk and reflect on the dilemmas of the lives that lie before them (Bois-Reymond, 1998; Pais, 2001; Thomson et al., 2002, Holland and Thomson, 2009; Brannen and Nilsen, 2002).

However, it is fair to say that the analytical focus of the transitions to adulthood paradigm has mainly been oriented towards transitions and their (un)planned consequences, experienced further along the life course (in which leaving school is an important point of departure). It has left adolescence (where so many decisive events and choices actually take place, in our view) as a rather grey area that may or may not emerge in the young people's $a$ posteriori accounts of how their past influenced their present or future (Pappámikail, 2004).

Indeed, childhood and adolescence are particularly framed by institutional demands on account of attendance at school, which submits individuals to compulsory calendars that act upon their life experiences. Due to the generalization of schooling and its transformation into the most legitimized form of social validation, schools become, in principle, the best place to prepare future life projects. In fact, the educational institution invites pupils to invest in their studies and has a leading role in introducing the need to project themselves 
into the future and exercise the art of planning. The purpose of the pupils' families, and especially parents, seems to converge (Zanten, 2009; Vieira, 2009; Sebastião, 2007/2008; Diogo, 2008; Seabra, 2010), as they push their children forward to project themselves into adult calendars in order to succeed in the 'trials' that the school represents. Long-term projects, fixed to a greater or lesser degree, are the aim (Reay and Ball, 1998; Brannen and Nilsen, 2002, 2007).

However, the parents' long-term projects frequently contrast with their offspring's experience, which is rooted in the present (Resende, 2010), based on the postponement of the future (Brannen and Nilsen, 2002). As we have stated, adolescence can be a period of intense exploration and some turbulence for many (Le Breton, 2008), as individuals are dealing with the double process of growing up and maturing, which is carried out with hesitant advances and retreats (Breviglieri, 2007). This 'biographical uncertainty' experienced by adolescents (though also young people in general) in relation to 'the great difficulty - sometimes a refusal, sometimes the inability - to project oneself into the future by means of decisions made in the present' (Leccardi, 2006: 32) may explain why, for some adolescents, the fact of being irreversibly committed to a future project represents a real difficulty (as Bois-Reymond found among young adults in the Netherlands, 1998; on this subject, see also Devadson, 2008; Woodman, 2011).

Thus, no other process illustrates the paradoxes inherent in the experience of adolescence so effectively as the trial of schooling and the construction of a vocational pathway. Moreover, the Portuguese educational system is a particularly appropriate example to capture these individuation paradoxes. In contrast to other European educational systems (such as in Germany, where the system allocates pupils to different tracks at a very early age, depending on their academic performance; or France, where the school recommends the appropriate school path/educational direction to the family, according to the pupil's academic reports, at the age of 15), the Portuguese educational system places the students at the centre of the process of defining their future, by inviting them, at a rather early point in their biographies (by the age of 15), to formulate a vocational choice - one that is ideally autonomous and free of any institutional constraints. ${ }^{2}$

In fact, when faced with the obligation to commit themselves prematurely to a certain future or faced with a large range of possibilities, do young people submit to this imposition by risking their chances in a 'just-to-have-a-look' attitude, trying not to mortgage the present (Rayou, 2007)? If, especially at this transitional stage, identity is a provisional commitment that implies combining several individual features based on fragmented experiences acquired at a time dedicated to exploration and self-knowledge, and the choice of a vocational pathway is a task that requires subjective composition work from individuals, how do young people try to combine the need and/or will to risk (life pathways) and the - more or less conscious - assumption of the risks of failure and/or disappointment? These are some of the questions we will try to explore. 


\section{Data and methods: analysing schooling narratives}

In sum, pupils that reach upper secondary education in Portugal are compelled to make decisions 'individually' and be responsible for the consequences, independently of their willingness and confidence. A process that, taking into account the uncertainties experienced and the projected risks, demands some form of individual reflexivity (Archer, 2003; Dubet, 2005; Giddens, 1991; Thévenot, 2006).

The analysis that underpins this paper is drawn from qualitative data collected within the project 'Open future: uncertainty and risk in school choices', a recently finished research project sponsored by the Portuguese Science and Technology Foundation. ${ }^{3}$ The most suitable methodological approach to address the research issues explained above was indeed to examine the meanings attributed by individuals to their experiences and life worlds (Warren, 2002).

More precisely, it makes use of 24 in-depth individual interviews with pupils attending three upper secondary state schools, following the survey (8 interviews per school) and thus assuring different educational contexts and social publics.

The first school (A, involving interviewees 1 to 8 ) is located in a small town in a rural area of the country and offers a diverse range of general and vocational courses. As the sole upper secondary school in that region, it recruits pupils from diverse social backgrounds, though mostly from lower middle- and working-class origins. Of the 8 interviewees, 3 had failed (and therefore repeated) at least one year before entering secondary school. The second school (B, interviewees 9 to 16) is located in a Lisbon residential neighbourhood and only offers general courses leading to higher education. Most pupils come from upper- and middle-class backgrounds and the overall academic level is high ( 1 out of 8 interviewees had repeated a year). The third school (C, interviewees 17 to 24$)$ is in a former working-class area of the capital and only offers vocational courses. The great majority of pupils come from low-income households and some of them do not want to extend their studies to higher education - the majority of interviewees $(5 / 8)$ have repeated a year at some point in their school careers. In all, 12 male and 12 female pupils were interviewed: on the one hand, 8 had upper/middle-class origins and 16 were from lower middle-class/working-class households; on the other, 14 were attending more academic courses and 10 more vocational courses. In order to capture the processes of and justifications for the schooling choices made, on the basis of different time-related experiences, a cross-sectional sample of pupils at the beginning (10th year) and end (12th year) of their secondary school trajectories was included (12 pupils each).

The field work took place from April to May 2009. All the appropriate ethical procedures were followed: interviews were arranged with the agreement of the local school authorities and with the informed consent of the 
participants' parents (whenever pupils were minors) and, most importantly, participation was voluntary. The interviews were recorded and conducted within the precincts of each school, in a place specially allocated for this purpose. Following the suggestion of Eder and Fingerson (2002), the interviewers tried to ensure that the interview context was as natural as possible and, whenever the interviewees showed a certain resistance in sharing their views and experiences, they tried to reduce the strangeness (eg by adopting a more informal style of language, thus reducing the cultural distance, or by trying to overcome the unequal power dynamics, with the introduction of a certain degree of reciprocity and self-disclosure). ${ }^{4}$ Thus, the choice of a semistructured interview script proved to be the most adequate, due to the flexibility that this kind of interview protocol allowed the interviewers, ensuring at the same time that all the subjects were explored (Warren, 2002). The conversation topics started with the pupils' past and present schooling experiences, with an in-depth analysis of the process of choosing a vocational path. The aim was, in particular, to make interviewees talk about possible obstacles or dilemmas encountered and to understand their justifications for past decisions and the choices they are expected to make in the near future. Future plans and support networks were also thoroughly investigated. The information obtained was then subjected to a content analysis process (thematic categorical analysis) in which we mainly looked for commonalities and themes that cut across the sample despite the objective differences in the interviewees' social profiles. This took into account some of the categories in the interview script, inspired by the theoretical background, and some new ones that emerged from the material (Boyatzis, 1998; Ryan and Bernard, 2000; La Rossa, 2005). These categories were grouped under broad themes: for example, assessment of the school trajectory; meanings awarded to schooling; the process of choosing a vocational direction; the reassessment of options; uncertainties experienced; dealing with uncertainties; and future plans. These were crossed, as far as the limited number of cases at our disposal allowed, with aspects such as location, social origins, etc.

An important final methodological note should be added: in this paper, we are only dealing with 'stay-at-school' trajectories. At the time our fieldwork was completed (school year 2008/2009), compulsory education in Portugal was still fixed at 9 years of study, that is, until the pupils were 15 years of age. This meant that after lower secondary school, the possibility of leaving the education system was an available option, although this challenging subject was not explored in this particular research project.

\section{Choosing a vocational pathway: risking uncertainties}

Constructing a school trajectory that is part of a life project represents a complex task. In the first place, making a vocational choice is a process constrained by the education system's compulsory calendars. Moreover, it implies 
dealing with three different considerations. First, it requires cognitive, informational, relational and planning skills; in a word, reflexivity. Secondly, it involves a plural set of social agencies (school, media) and actors (family, teachers, peers, counsellors). This reinforces the importance of both support networks and social and economic resources (Reay and Ball, 1998; Reay et al., 2001; Threadgold and Nilan, 2009). Lastly, choices are supposed to be the means of attaining self-fulfilment and, therefore, to be the reflexion of the 'true' self (Taylor, 1989) or the best way to achieve the desired 'self' (Honneth, 1995, 2007).

\section{Self-accomplishment as the main life goal}

Self-accomplishment is a general goal that every pupil wants to reach. However, this life goal is composed of multiple and changing attributes, depending on the circumstances and interpretations (Honneth, 2007). Authenticity, one of them, corresponds to the more expressive interpretation of autonomy as a cultural value within the framework of modern individualism (Pappámikail, 2009; Taylor, 1989). Actually, one of our most important findings is the fact that authenticity emerges in pupils' discourse as the main normative reference used to talk about their school trajectories, justifying options and pathways. In fact, individuals generally seek to be faithful to themselves, either to what they always have been, or to what they wish to be in the future. The discourse of Interviewee 13 illustrates the emphasis given to self-fulfilment and authenticity. She chose art as her upper secondary area; it was something that was 'revealed' to her at an early age:

'Over the years, I was always inclined towards art, I didn't have a specific course defined, but I always wanted to go into this area (...). Even if I was worried in the beginning because being in this area could be a problem in the future, in terms of employment and opportunities, my parents always told me that if that was what I wanted, then that was what I should be doing. It is easier for a person to be good at something they like than at something they don't.' (Pureza, girl, 12th Year, General Art, School A, no years repeated, middle class)

As Bernstein says (1983: 10), to exhibit autonomy it is not enough that decisions are made by a person; they have to be his or her own. Individual choices should not only reflect a person's thoughts and ideas, they should also be their consequence, which implies a degree of control over them (Pappámikail, 2009: 27). Thus, autonomy (if defined as the ability of the individual to make decisions) and personal accountability are also important in the students' discourse. As Evaldo says:

'The guidance I had from my parents was that they wanted me to go to university. (...) They gave their guidance but that wasn't conclusive. It was 
me who took the decision [to do the present course], it had to be me.' (Evaldo, boy, 10th Year, Vocational Sports, School C, 1 year repeated, working class)

As argued, that kind of control may be hard to achieve in adolescence, due to the complex and uncertain identity construction process that students are undergoing at the same time as they have to choose their school options. Sometimes the goal is a precise area of interest:

'(...) I always loved cars and everything to do with cars and then I tried to see if there were courses ... I looked things up on the internet and searched around to see if there were courses and this was the one I picked, Automobile Mechatronics. (...) I looked up all the schools that had this course, applied to several and then came to this one.' (Fábio, boy, 10th Year, Vocational Mechanics, School C, 1 year repeated, working class)

Other times, the students only mention a scientific field or vague professional area:

'The subjects I liked most were history, geography and Portuguese. Afterwards, I started to be more interested in reading, I started to read more and maths was not so much my area. (...) And in the range available in our school, humanities, that is the area I went into, has Portuguese and history as major subjects. I knew it was the right one. I didn't know what I wanted to follow afterwards but I knew that was the area I fitted into best.' (José Maria, boy, 12th Year, General Humanities, School B, 1 year repeated, middle class)

In all cases, at crucial moments that involve some kind of decision, although the students are constrained, they engage in an exercise of reflexivity, where some provisional balance must be found between their individual inclinations, vocations, abilities and/or dreams and the actual options the system offers.

This may be especially difficult because, on the one hand, the feelings of certainty about choices vary. Not all interviewees, like some already quoted, reported vocational convictions based on early dreams cherished over the years. On the other hand, the school system itself appears to many, mainly among the less favoured in terms of resources, as an opaque and complex web of multiple options in which pupils are forced to navigate with highly asymmetric support structures. As Singly (2000) points out, there are limits to societies ruled by a certain kind of individualism: the distribution of the material and symbolic resources necessary to access and exercise autonomy is unequal (see also Nilsen et al., 2001). Thus, in many cases, balances may rapidly become imbalances and a source of anxiety and uncertainty.

It is, therefore, more accurate to talk about goals of self-fulfilment and the wish for authenticity framed by an actual field of possibilities. To a great extent, 
school options seem to be dependent on individual and contextual variables, despite accessibility being guaranteed to each and every pupil by the formal principles that structure the Portuguese education system. In terms of individual variables, previous school performance (failure at school before entering upper secondary education) is one, if not the most, fundamental element, as it informs the pupil (and others) of his/her actual skills and abilities, independently of previous desires or dreams. But the pupil's parental resources and, specially, the quality of educational support that parents are able to offer to prevent or to remedy their children's low achievement (eg early diagnosis of difficulties; intense parent-teacher communication; expert guidance, where possible, to cope with problems) also influence the possibility of making their dreams come true.

José Maria and Aníbal's trajectories clearly illustrate this point. Both failed at school but their parents' educational support to help them regain their form academically was quite different (in content and outcomes).

The first student came from a middle-class home in Lisbon and attended a Catholic private school from the very first years of schooling. When he was having difficulty with mathematics in the 7 th year, his parents paid a private teacher to give him extra lessons - a preventive solution that was repeated successfully in the following two years. By the 9th year, José Maria began to play rugby as a regular extra-curricular activity. His passionate dedication to this sport had a direct consequence: a decline in investment in his studies. As his academic results began to deteriorate, his teachers warned the family and his parents encouraged him to study more. Instead of doing so ('I didn't want to study as an obligation'), he began to 'read a lot [of literature]'. That did not work and at the end of the school year he failed. His parents had a long conversation with him and told him he had to reverse his unsatisfactory performance the following year, in which he had to achieve good results from the very first months - or leave the rugby behind, 'the worst punishment I could ever have'. His parents' strategy worked perfectly and he turned out to be an excellent pupil. At the time of the interview, he was intending to apply to a specific law faculty in Lisbon, after receiving some friends' advice and his parents' support, combined with professional information:

'My father is also a lawyer and my mother is a law graduate, so talking to my father ... practical cases my father tells me about and all ... interesting (...) and I have been searching the net with my mother. That law faculty has good teachers who are associated with the history of law in Portugal, with the Constitution and all ...' (José Maria, boy, 12th Year, General Humanities, School B, 1 year repeated middle class).

Aníbal, in contrast, is the eldest son of a farming couple with little education. They live on the outskirts of Lisbon. He wanted to be a physical education teacher but the course was not on offer at the secondary school to which he had moved after his basic education (Years 1-9). Compelled to attend the 
course in general science that was available, though it did not really motivate him, he began to hang around and have fun, not worrying about his studies: ‘. . and that began to show up in the school results ... if you get a bad result in a subject in the first term, it's not worth studying much in the second and third terms ...' Not having any specific parental or expert support to cope with the difficulties, he failed that year (the 10th). The following year, as things were getting worse, he quit school and went to work with his parents on the farm. After working hard for two years - and becoming more mature - he felt the need 'to enrol in a vocational course to complete at least the 12th year of schooling ...' Seeing the technological windmills in the landscape that surrounded his work place, he became interested in renewable energies and, with the help of some friends and internet research, discovered an occupational course that matched his interests. His parents' support was important at an emotional level (encouragement and the approval of their son's decision to return to school) but was very limited on an educational level. Aníbal had to find his way in the new school. At the time of the interview, as he was more mature and highly motivated, he was considering going on to higher education: 'Now I want to catch up on all the time wasted . . I'm twenty, this course lasts three years and I want to reach the age of twenty seven years, at the most, with everything completed - including a higher education, so . . ' (Aníbal, boy, 10th Year, vocational course, Sustainable Energy, School C, 1 year repeated, working-class origin)

With regard to contextual variables, limitations on the range of courses locally on offer seem to be a significant constraint on students' choices. Aníbal is an example of these constraints, which are particularly evident when only one secondary school is available, as is the case in small towns. We often heard explanations/justifications such as those given by the interviewees in school A. One example is Paula, who enrolled in a vocational course in tourism because 'it was the only alternative available'. Later, she confessed that part of her lack of motivation at school was to do with the fact that 'of the vocational areas that the school offered, there were none that inspired me' (Paula, girl, 10th Year, Vocational Tourism, School A, 2 years repeated, working-class origin). It is important to note, however, that the more assured the pupils are of their vocational choices at the time of the critical decision, the more active they are in trying to overcome any obstacles that may emerge:

'I don't really know how I got this idea (...) but then I found that I wanted to do economics and I felt it very strongly. (...) They [the school authorities] told me that [an economics course] might not be available in this school because there weren't enough pupils and then I thought that if it isn't available here, I'll have to change schools [to another, far away] because I won't do anything else.' (Cristina, girl, 12th Year, General Economics, School A, no years repeated, working-class origin)

Although decisions refer to a specific moment, choices are processes that develop within a time frame and are thus closely linked to daily experience. 
This involves expectations that informed choices are later on confronted with actual experience during secondary education (from the 10th to 12th years). In some cases this confirms expectations, thus validating and legitimizing previous choices (giving young people the idea that they correspond to what they always wanted); in other cases experience leads to disappointment, giving way to discourses in which the pupils are forced to (re)compose their vocations and choices. Furthermore, there are cases when it is even possible to talk about misleading trajectories, especially in those situations where initial decisions were taken with little information to support them or were largely influenced by institutional pressure. In these cases, mainly encountered among pupils whose parents have few educational resources to offer, the young people realize, later on, how they were misled by inaccurate information about their school options, with quite serious consequences for their near future. Carina, for example, a girl from a working-class household who is in the first year of a vocational multimedia course, believes she was misinformed:

'... because when I came to fill in my application form, there were two courses. I explained what I wanted and the lady told me [to apply for one] and then I saw that it wasn't what I wanted and that's why I think I was misinformed. (...) I felt that the course was more for boys than for girls, and then I didn't identify with it.' (Carina, girl, 10th Year, Vocational Multimedia, School C, 1 year repeated, working class)

The priority given by the students interviewed to personal fulfilment in both the present and future may be seen as evidence of the widespread dissemination of the more self-expressive elements of contemporary individualism (Taylor, 1989), which should not, however, be interpreted as a rejection of the materialistic elements related to social mobility and professional and economic success (Pappámikail, 2009). Despite more importance being given to 'authentic' vocations, pupils tend to express the desire to follow options that allow them to combine both elements successfully. Salvador, a boy of middleclass origins, clearly stresses this normative double track:

'I always wanted to be a vet. I always had that dream and that was basically

it: to do a university degree. Not because of my parents (...) but for personal success and to try to be someone in life.' (Salvador, boy, 12th Year, General Science, School B, no years repeated, middle class)

However, a dilemma emerges when young people find themselves in a situation where they believe they have to choose between an option that they want and like, though it implies a higher risk of being unsuccessful, and one that may be good and/or safer. Sonia is an example of this phenomenon. When she reached secondary education, she was already inclined to follow an art course but felt insecure and listened to her parents' advice instead. They thought it was a waste of time (architecture, her initial goal, is believed to be 
a very competitive and inaccessible professional market). She ended up completing her secondary education, the first time, in humanities, with the idea of doing a law degree - a course that, in fact, she knew she did not like. At 18, however, she decided to start again, despite her parents' disapproval:

'I tried to show my mother that that was what I wanted. What we want isn't always the best thing but that was what I wanted to do and I decided to bank on it. In our life, we have to go for it and decide on things. (...) I preferred to do something I liked and take a risk than do something that I didn't like and ... then it would be a waste of time.' (Sónia, girl, 12th Year, Vocational Design, School C, no years repeated, working-class origins)

In sum, despite the different meanings attributed to self-accomplishment, whether in favoured or less privileged social contexts, it is important to underline that authenticity, as the urge to be faithful to oneself, tends to be at the centre of a fairly universal normative grammar mobilized by students when they are invited to compose their school narratives and justify their choices. This is especially true when there is some kind of vocational dilemma. The norm of authenticity seems, in fact, to help to sustain the act of risking a vocational pathway, despite that fact that it is risky.

\section{Dealing with (un)certainties and risks}

As mentioned above, compulsory choices may be a constraint for pupils due to the strict calendar in which decisions have to be made. The possibility that these times may generate feelings of anxiety and uncertainty has been underlined precisely because every choice is, to some extent, related to virtual risks of failure in the future. It is important to stress, however, that analyses have shown that the confidence with which these feelings are faced can vary greatly according to the young peoples' past and present performances, their information on and awareness of institutional alternatives and/or their economic and cultural resources (which act as a buffer for possible setbacks in the students' school trajectories). Moreover, these three elements are frequently combined, reinforcing asymmetries in the opportunity structures that young people actually have to deal with while building up their school (and life) projects.

Despite the unavoidable diversity, our analysis allowed us to identify different sources of uncertainty in the students' discourse.

First, the transition to secondary education (more demanding, more competitive) may affect the young people's self-image as pupils (Reay and Wiliam, 1999; Reay et al., 2001). Good pupils may discover that they are no longer as good or their school performance may be insufficient to pursue initial academic objectives. Uncertainty rises because schoolwork, at this level of education, is less closely supervised than in lower secondary education and it has implicit requirements (Barrère, 2003) that pupils have to satisfy and decode on their own. Ultimately, as expected, this transition in the nature of schoolwork 
affects, in particular, pupils who have performed well in their previous school careers and are engaged in competitive options, that is, mainly courses leading to highly selective fields of study in tertiary education. João, who is studying science and technology, faced unexpected difficulties:

'Let's put it like this ... there is pressure but, at the same time, there is motivation. At present, it's more about motivation because I've never got into the habit of studying ... I've always had good grades, even very good ones. But, for instance, biology is a subject that requires a lot of memorizing, a lot of names, and I have to study. I really must get into the habit of studying. (...) There's a big difference (compared to the 9th year). We haven't realized yet that the upper secondary level is different from lower secondary education.' (João, boy, 10th Year, General Science, School A, no years repeated, middle-class origins)

This gap between a student's past and present identity also puzzles Francisco, who has based his future prospects on previous good grades. An unprecedented series of doubts about his actual capacities has emerged, as his present grades may not be sufficient to reach his goal of studying medicine (one of the most difficult courses access in Portugal):

'It was easier - now it's more difficult to get good grades and, well, I was motivated by the goal of attaining good grades but I really didn't worry too much. (...) I aimed to study medicine at the beginning but afterwards things got worse and now I really don't know how to manage. So I must try to improve ... that's my goal, to improve further, the higher the grade I get, the better ...' (Francisco, boy, 10th Year, General Science, School B, no years repeated, lower middle-class origin)

Secondly, expectations created before the transition to secondary education are compared with actual experience (of subjects). Simultaneously, young people are undergoing a maturing process which translates into more elaborate reflexivity skills and greater overall self-knowledge. The combination of these two processes may raise doubts in relation to former certainties, which leads to a redefinition of interests. This is the case of Carlos, who is studying multimedia in a vocational secondary school and finds that his choice is being challenged by unexpected and uninteresting subjects.

'Physics and chemistry are, I think, quite boring? I can't get into these subjects, digital systems and computer design and so on, (they) are connected to computer programming and architecture ... This year I don't quite fit in, it's a subject I really didn't expect to have. (...) Perhaps that's why, this year, I feel a certain unwillingness to finish this course.' (Carlos, boy, 12th Year, Vocational Multimedia, School C, no years repeated, lower middle-class origin) 
Lastly, uncertainties can be associated with the perceived possibilities of succeeding with future plans. In fact, almost all students become increasingly familiar (as they advance in their upper secondary studies) with both the education system and the dynamics of the labour market, the latter of which are largely unpredictable. This demands the constant re-evaluation of contexts and performances in order to adjust provisional projects to changing scenarios. And this is something that they cannot do without mobilizing the competencies and resources available. For instance, the academic results that gave access to a given university course ${ }^{5}$ last year may not be sufficient to guarantee acceptance this year. This is particularly stressful for those who are about to finish their upper secondary education (the 12th year), as Cristina points out:

'I have some fears about the exam, the maths examination. It will decide everything because it's the only examination subject that will give me access to university, but I'm trying hard to get a good mark.' (Cristina, girl, 12th Year, General Economics, School A, no years repeated, working class)

The experience of uncertainties, no matter how unequally distributed, compels young people to create solutions to overcome or at least mitigate such feelings.

Ensuring reversibility, to start again, is one of the solutions some pupils mention. If reversibility is a commonly recognized cultural feature of contemporary youth trajectories (Biggart and Walther, 2006; Pais, 1996, 2001), most pupils have ambiguous attitudes towards it because any decision that implies going back into the education system means wasting (their) time. Therefore, reversibility tends to be a last resort, but a resort anyway, at least at the narrative level. This ambivalence is clearly expressed by Martim, whose choice of a general secondary course leading to a higher education course in management involved a degree of uncertainty over future prospects:

'And afterwards, independently of the option I'll choose out of the three, I can always go back (...) It's no big deal ... (...) When I take decisions in my life I don't think I'm going back, of course not, because it's better to think and decide than go backwards all the time. Now, if I do a course I really don't like, that I'm not enjoying at all, I'm not going to spend five years of my life studying something I don't like.' (Martim, boy, 10th Year, General Economics, School B, no years repeated, middle-class origin)

To avoid this situation, some pupils mentioned opting for the postponement, as long as they could, of choices involving commitment (which is consistent with the evidence discussed by Bois-Reymond, 1998; Devadson, 2008, and Woodman, 2011, among others). They opted for the track that gave them broader opportunities in terms of university courses or, for those pursuing vocational education, in terms of staying in the education system and delaying their transition to the labour market. In fact, this solution of postponement 
seems more popular in the former category than the latter, thus raising the 'project paradox' that Dubet and Martuccelli (1996) have extensively explored: the more pupils have to project themselves into the future, in terms of academic success and resources, the more tempted they are to stake their future solely on their school performances and extend their pupil status to the utmost. In contrast, those who do not show such qualities are compelled to seize (more precociously) the only school options left open to them. So the 'project' narratives produced by the education system induce, precisely, those who have fewer choices to choose and be responsible for their options (Reay et al., 2001; Brannen and Nilsen, 2005; Woodman, 2011). Margarida illustrates the first profile; Joel is an example of the second:

'I don't know ... I'm still undecided about . . . business administration. At the moment, I want to do business administration but I have also considered economics, but I have the feeling that it might be boring (...). I see business administration as a broader BA course ... it's more than decided, I want to do a master's degree. Afterwards, I can take a suitable subject in whatever I want to do: a master's degree in international hotel management for example (...) then I will decide ...' (Margarida, girl, 12th Year, General Economics, School B, no years repeated, upper-class origin)

'Well, I carried on studying after the 9th year because . . in a sense, it was the way pre-defined by my parents and also because, in the 9th year, I wasn't quite prepared to drop out of school to enter the labour market. I hadn't chosen a profession yet and I didn't feel prepared for it ...' (Joel, boy, 12th Year, Vocational Mechanics, School C, 1 year repeated, lower middle-class origin)

To mitigate anxiety related to uncertainties about the future, some pupils prefer to follow a step by step approach to school challenges, in what may be seen as an expression of the adolescent time scale discussed earlier (to concentrate on the present rather than the future in order to cope with everchanging scenarios). Thus, they say that they prefer dealing with problems as they appear, avoiding long-term concerns and plans and concentrating on the short-term trials (to pass the school year, to improve their marks next term). Interviewee 9 adopted this solution, believing it the best way to limit anxiety:

'Life is like this, I have goals ... In the 5th year I said to myself "I want to finish the 12th year and go on to university; but, for now, I want to complete this year, then I want to finish the next" ... . and I have to do it step by step, because if now in the 10th year I'm already thinking I won't get into any university or any job at all, I can't concentrate on the present ... OK, the future is important, but we have to think about it when the time comes. (...) We are going to have our final (secondary education) examinations, of course we are, but if I think about it now, how will I concentrate on "now"? 
I'm always saying: “I won't get through".' (Mariana, girl, 10th Year, General Humanities, School B, no years repeated, lower middle-class origin)

Similar reasoning is expressed by Fábio, who is following a vocational secondary course:

'No, my goal was always to conclude the 12 th year and then we'd see if I went on to university or not.' (Fábio, boy, 10th Year, Vocational Mechanics, School C, 1 year repeated, working class)

Regardless of the solution found to deal with uncertainties, however, the majority develop alternative plans to cover the chance of failing to achieve any of their specific goals. And these differ, according to the stage they have reached in their school trajectory and to their support resources: if some deal with the possibility that they will fail to get onto their first-choice university course, others project possible difficulties in entering the labour market in the area of their vocational training:

'I've not thought about it well enough, but one of my goals is to finish this (vocational) course. If I manage to get a job in this professional field, it'll be excellent because nowadays things are difficult ... difficult for everyone (...) and I've always dreamed of having my own things, to be independent ... all that ... (...) This is my first option ... My second choice, if I can't get a job ... I'll apply for the army (...) ... as a third choice, I'll go to university.' (Fábio, boy, 10th Year, Vocational Mechanics, School C, 1 year repeated, working-class origin)

In sum, to be focused on the present, refusing a final commitment and considering various possibilities - and thus keeping their options open as long as possible - is one of the solutions many young people resort to in dealing with uncertainties and avoiding risks caused by the institutional imposition to construct a project (for some students, at least) before they are ready.

\section{Virtual risks, uncertainties experienced, risking a pathway: final remarks}

Using young people's accounts of their school trajectories as a point of departure, with the broad goal of discussing the adolescent individuation process in light of the current ethical landscape of contemporary societies, which promotes values like autonomy and self-accomplishment, and simultaneously the risk and uncertainty that cuts across every sphere and stage in life, we explored secondary students' explanations for their vocational choices and scanned young people's projects, desires, fears and (un)certainties. We tried to discover the ways in which young people compose their pathways, responding to the 
normative obligation to become autonomous individuals (free, fulfilled, authentic) and always taking into account the intrinsic diversity of their life situations (unequal in terms of resources and different in the stage reached in their school trajectory), which ultimately help to shape the breadth of each pupil's field of (schooling) possibilities.

One of the more striking conclusions of our analysis is the fact that while choosing a pathway or direction is compulsory, it does not tend to affect the importance attributed by adolescents to self-accomplishment as the ultimate life goal. In fact, young people's main commitment seems to be to themselves, that is, to being faithful to their inclinations, tastes, dreams and/or talents, in what may indicate the central place authenticity occupies in their explanation grammars, especially when faced with a vocational dilemma. When compelled to choose, the majority risk following what seems, at the moment of choice, to be the pathway that best fits what they are and/or what they want at the moment for their future, with its imprecise plans, dreams or fantasies (Pais, 2003; see also Devadson, 2008).

However, evidence has also shown that, to make a vocational choice that is supported, to some extent, by the family and/or experts implies mobilizing the reflexivity skills available: young people have to project their provisional self into the future, taking into consideration past school performance, the alternatives in the education system and some kind of self-knowledge. In fact, more than translating into narratives of perceived risks (as in Beck's definition), school options imply, more frequently than not, uncertainties and biographical doubt and hesitations. To choose a vocational direction is, thus, an ongoing process that goes far beyond the moment of decision itself, as choices end up being compared with actual experience, individual performance and the reformulation of the student's desires and inclinations. In addition to this individual dimension, moreover, the issue of changing contexts and institutional settings (in particular in education - in Portugal, they change each year due to the numerus clausus model for HE entry - and in labour market dynamics, with youth unemployment rising, especially among qualified young people), the availability of economic and cultural resources and the strength of support and informational networks emerge as crucial factors that shape the nature of the virtual risks and the uncertainties experienced that students refer to in their discourses. In fact, in sharp contrast to those from less favoured origins, interviews show that children whose parents are more familiar with the education system tend to perform better academically when moving to upper secondary education (which acts as a buffer against the risk of future failure at school). Furthermore, they are mostly integrated into the most selective school options (general education), which are oriented towards long school careers and thus allow them to delay facing the uncertainties of a more definitive choice. Therefore, to risk taking a certain educational direction points to a wide range of life experiences and prospects: from concerns of material survival to ambitions of being integrated into highly selective and competitive professional markets, there 
is a considerable distance that cannot be solely reduced to individual processes of choice and individual performance.

Nevertheless, we have argued that contemporary individuation in adolescence has specificities that are linked both to the life cycle stage - age elements - and to changes in the ethical and cultural background (that tend to emphasize expressive individualization values) - generational elements. These elements may be foreseen in the tense articulation between the institutional and adult reference time frame and that of the adolescents. Therefore, in the context of constructing a school trajectory, the need and wish to explore and discover oneself may lead to a general attitude of risk-taking despite the risks, albeit within reasonable limits. Even though informational resources vary according to the students' social positions, which underlines the persistence of inequalities linked to the education system, young people do not seem to be blind to the possible scenarios of failure in the future, which consists of a series of uncertainties after all. This is clearly demonstrated by the fact that they not only express these uncertainties, though they differ in nature and extent, but find ways to deal with them.

In addition, young people seem to be forced to find a way to accommodate an uncertain future in their present, without transferring the core of their existence as young people into the future. Precisely because of this, the concept of risk, widely used in contemporary research and traced back to Ulrich Beck's seminal work (1992), emerges as an adult-centred notion not necessarily related to students' experiences. These seem more likely to be anchored in the present and in the commitment to explore and to fulfil themselves.

Thus, regarding individuation through schooling, the analytical emphasis should, in our view, be put on the non-linear and process dimension of the construction of school (and life) trajectories: on what, essentially, constitutes an exploratory path constructed within the constraints and opportunities shaped by each individual's (unequal) social position. Here, there is room for hesitation, uncertainty and insecurity, which may translate, in Breviglieri's words (2007), into a 'doubtful self' that nevertheless sees risking a pathway that leads to an imagined future as an important aspect of the grammar explaining young people's identities.

University of Lisbon

Santarém Polytechnic Institute

New University of Lisbon
Received 30 March 2011

Finally accepted 1 June 2012

\section{Notes}

1 Under the Salazar dictatorship (1933-1974), the policy of strictly containing industrial development meant that the Portuguese economy retained its traditional rural features, which were based on a poor, low-paid and fairly illiterate workforce. Compulsory basic education lasted four years (until 1964, when it was raised to six) and it was not uncommon for children to drop out of school. This explains why the proportion of Portuguese people with a poor education (4 
or 6 years' study) is still high today (38 per cent). Only at the beginning of the 1970s, with the industrialization and tertiarization process that the country witnessed and then the restoration of democracy in 1974 did schooling acquire a new relevance, on both the political and individual levels. On the one hand, educational policy was clearly committed to the expansion of the educational supply, as well as to tackling failure and early leaving. At present, 12 years of full-time compulsory education are the rule and even though social inequalities continue to have an impact on access and 'survival' rates, the diversification of school careers - with the inclusion of different types of vocational courses both at the basic and secondary levels of education - have helped to reduce this inequality. On the other hand, education has been increasingly recognized by the Portuguese as an important social asset and an important aspect of self-development (Almeida and Vieira, 2006). The dramatic fall in fertility rates in Portugal in the last thirty years is largely connected with the symbolic and educational investment that households make in their children (Almeida, 2005; Wall, 2005), with a view to reaping future social advantages.

2 This 'free-choice model' was adopted by the Portuguese educational system as reverse reparations for the 'streaming model' that existed before the restoration of democracy in 1974, which was seen as reproducing social inequalities. The latter was built on two distinct, noninterchangeable tracks - academic schools ('liceus') and vocational schools ('escolas técnicas') - that were attended by pupils with socially different profiles (the more advantaged and disadvantaged, respectively).

3 The project 'Open future: uncertainty and risk in school choices' (FCTn ${ }^{\circ}$ PTDC/CED/67590/ 2006). This research project used a range of observation scales (between the macro- and micro-levels): a survey of pupils $(n=1793)$ attending upper secondary schools, observation (teachers' collective work-meetings), documentary research, and interviews with different social actors (parents, school teachers and vocational guidance experts).

4 Eder and Fingerson (2002) stress the fact that interviewing children and adolescents 'presents researchers with unique opportunities and dilemmas'. If it is true that it allows adolescents to talk about their life experiences in their own terms and words, we cannot forget that in-depth interviewing is always a specific performance in time and space with a very particular audience (the researcher): the epistemological status of the information collected must be discussed in light of this fact (Johnson, 2002; Reissman, 2002). This is even more important when interviewees may interpret the interview moment as a moment of symbolic violence due to unequal status in terms of power (culture and/or age) (Bourdieu, 1993; Eder and Fingerson, 2002).

5 In Portugal, entry to higher education is restricted by a numerus clausus system that limits the number of students accepted for each course. The number of places available is fixed annually. Applicants are ranked according to their results at the upper secondary level and their classification in the national admission examinations.

\section{References}

Almeida, A.N., (2005), 'O que as Famílias fazem à Escola . . Pistas para um Debate', Análise Social, XL (176): 579-594.

Almeida, A.N. and Vieira, M.M., (2006), A Escola em Portugal, Lisboa: Imprensa de Ciências Sociais.

Archer, M.S., (2003), Structure, Agency, and the Internal Conversation, Cambridge: Cambridge University Press.

Arnett, J.J., (2004), Emerging Adulthood: The Winding Road from the Late Teens through the Twenties, Oxford: Oxford University Press.

Barrère, A., (2003), Travailler à l'École: Que Font les Élèves et les Enseignants du Secondaire?, Rennes: Presses universitaires de Rennes.

Bauman, Z., (2001), Community: Seeking Safety in an Insecure World, Cambridge: Polity Press. Bauman, Z., (2007), Liquid Times: Living in an Age of Uncertainty, Cambridge: Polity Press. 
Beck, U., (1992), Risk Society: Towards a New Modernity, London: Sage.

Beck, U. and Beck-Gernsheim, E.,(2001), Individualization: Institutionalized Individualism and its Social and Political Consequences, London: Sage.

Beck, U., Giddens, A., and Lash, S., (1994), Reflexive Modernization: Politics, Tradition and Aesthetics in the Modern Social Order, Cambridge: Polity Press, in association with Blackwell.

Bernstein, M., (1983), 'Socialization and autonomy', Mind, XCII: 120-123.

Biggart, A. and Walther, A., (2006), 'Coping with yo-yo transitions. young adults' struggle for support, between family and the state in comparative perspective', in Leccardi, C. and Elisabetta, R. (eds), A New Youth? Young People, Generations and Family Life, 41-62, Burlington: Ashgate.

Bois-Reymond, M.D., (1998), 'I don't want to commit myself yet: young people's life concepts', Journal of Youth Studies, 1 (1): 63-69.

Bourdieu, P., (1993), 'Comprendre', in Bourdieu, P. (ed.), La misère du monde, 903-939, Paris: Seuil.

Boyatzis, R., (1998), Transforming Qualitative Information: Thematic Analysis and Code Development, Thousand Oaks, CA: Sage.

Brannen, J. and Nilsen, A., (2002), 'Young people's time perspectives: from youth to adulthood', Sociology, 6 (3): 513-537.

Brannen, J. and Nilsen, A., (2005), 'Individualisation, choice and structure: a discussion of current trends in sociological analysis', Sociological Review, 53 (3): 412-428.

Brannen, J. and Nilsen, A., (2007), 'Young people, time horizons and planning: a response to Anderson et al', Sociology, 41: 153-160.

Breviglieri, M., (2007), 'Ouvrir le monde en personne. une antropologie des adolescences', in Breviglieri, M. and Cicchelli, V. (eds), Adolescences Méditerranéennes, 19-58, Paris: L'Harmattan.

Devadson, R., (2008), 'To plan or not to plan? Young adult future orientations in two European cities', Sociology, 42 (6): 1127-1145.

Diogo, A.M., (2008), Investimento das Famílias na Escola. Dinâmicas Familiares e Contexto Escolar Local, Lisbon: Celta Editora.

Dubet, F., (2005), 'Pour une conception dialogique de l'individu. L'individu comme machine à poser et à résoudre des problèmes sociologiques', EspacesTemps.net, available at: <http:// www.espacestemps.net/document1438.html>

Dubet, F. and Martuccelli, D., (1996), A l'École. Sociologie de l'Expérience Scolaire, Paris: Ed. du Seuil.

Eder, D. and Fingerson, L., (2002), 'Chapter 9 Interviewing children and adolescents', in Gubrium, J.F. and Holstein, J.A. (eds), Handbook of Interview Research: Context and Method, 181-201, Thousand Oaks, CA: Sage.

Elder, G.H., Johnson, M.K. and Crosnoe, R., (2003), 'The emergence and development of life course theory', in Mortimer, J.T. and Shanahan, M.J. (eds), Handbook of the Life Course, 3-22, New York: Kluwer Academic Publishers.

Furlong, A. and Cartmel, F., (1997), Young People and Social Change: Individualization and Risk and Late Modernity, Buckingham, Open University Press.

Giddens, A., (1991), Modernity and Self-Identity: Self and Society in the Late Modern Age, Cambridge: Polity Press.

Heinz, W.R. and Kruger, H., (2001), 'Life Course: Innovations and Challenges for Social Research', Current Sociology, 49 (2): 29-45.

Heinz, W.R. and Marshall, V.W. (eds), (2003), Social Dynamics of the Life Course: Sequences, Institutions and Interrelations, New York: Aldine de Gruyter.

Holland, J. and Thomson, R., (2009), 'Gaining perspective on choice and fate', European Societies, 11 (3): 451-469.

Honneth, A., (1995), The Struggle for Recognition: The Moral Grammar of Social Conflicts, Cambridge, MA: Polity Press. 
Honneth, A., (2007), Disrespect: The Normative Foundations of Critical Theory, Cambridge: Polity Press.

Johnson, J.M., (2002), 'In-depth interviewing', in Gubrium, J.F. and Holstein, J.A. (eds), Handbook of Interview Research: Context and Method, 103-119, Thousand Oaks, CA: Sage.

Lahire, B., (1998), L'Homme Pluriel, Paris: Nathan.

La Rossa, R., (2005), 'Grounded theory methods and qualitative family research', Journal of Marriage and Family, 67 (4): 837-857.

Le Breton, D. (ed.), (2008), Cultures Adolescentes. Entre Turbulence et Construction de Soi, Paris: Autrement.

Leccardi, C., (2006), 'Facing uncertainty. temporality and biographies in the new century', in Leccardi, C. and Elisabetta, R. (eds), A New Youth? Young People, Generations and Family Life, 15-40, Burlington: Ashgate.

Leccardi, C., (2008), 'New biographies in the "risk society"? About future and planning', 21st Century Society, 3 (2): 119-129.

Martuccelli, D., (2006), Forgé par l'Épreuve. L'Individu dans la France Contemporaine, Paris: Armand Colin.

Martuccelli, D., (2010), La société singulariste, Paris: Armand Colin.

Nilsen, A., Guerreiro, M.D.D. and Brannen, J., (2001), 'Most choices involve money: different pathways to adulthood', in Brannen, J. (ed.), Young Europeans, Work and Family. Futures in Transitions, 162-184, London and New York: Routledge.

Pais, J.M., (1996), ‘A Geração Yô-Yô: uma nova condição juvenil?’, in de Ciências Sociais, III Congresso Luso-Afro-Brasileiro Dinâmicas multiculturais, novas faces, outros olhares: as ciências sociais nos países de língua portuguesa e os desafios contêmporâneos, 111-125, Lisbon: ICS.

Pais, J.M., (2001), Ganchos, Tachos e Biscates, Lisbon: Âmbar.

Pais, J.M., (2003), 'The multiple faces of the future in the labyrinth of life', Journal of Youth Studies, 6 (2): 115-126.

Pais, J.M. and Ferreira, V.S. (eds), (2010), Tempos e Transições de Vida. Portugal ao espelho da Europa, Lisbon: Imprensa de Ciências Sociais.

Pappámikail, L., (2004), 'Relações Intergeracionais, Apoio Familiar e Transições Juvenis para a Vida Adulta em Portugal: Valores, Representações e Projectos', Sociologia, Problemas e Práticas, CIES, 46: 91-116.

Pappámikail, L., (2009), Juventude, Família e Autonomia. Entre a Normal Social e os Processos de Individuação, Lisbon: Universidade de Lisboa.

Rayou, P., (2007), 'De Proche en Proche, les Compétences Politiques des Jeunes Scolarisés', Éducation et Sociétés, 19 (1): 15-32.

Reay, D. and Ball, S.J., (1998), 'Making their minds up: family dynamics of school choice', British Educational Research Journal, 24 (4): 431-448.

Reay, D. and Wiliam, D., (1999), “'I'll be a nothing”: structure, agency and the construction of identity through assessment', British Educational Research Journal, 25 (3): 343-354.

Reay, D., Davies, J., David, M. and Ball, S.J., (2001), 'Choices of degree or degrees of choice? Class, "race" and the higher education choice process', Sociology, 35 (4): 855-874.

Reissman, C.K., (2002), 'Analysis of personal narratives', in Gubrium, J. and Holstein, J. (eds), The Handbook of Interview Research: Context and Method, 695-710, Thousand Oaks, CA: Sage.

Resende, J.M., (2010), A Sociedade Contra a Escola? A Socialização Política Escolar num Contexto de Incerteza, Lisbon: Instituto Piaget.

Roberts, S. (2010), 'Misrepresenting “choice biographies”? A reply to Woodman', Journal of Youth Studies, 13 (1): 137-149.

Ryan, G.W. and Bernard, H.R., (2000), 'Data management and analysis methods', in Dezin, N.K. and Lincoln, Y.S. (eds), Handbook of Qualitative Research, 2nd edn, 769-802, Thousand Oaks, CA: Sage Publications.

Sapin, M., Spini, D. and Widmer, E.D., (2007), Les Parcours de Vie: De l'Adolescence au Grand Âge, Lausanne: Savoir suisse. 
Seabra, T., (2010), Adaptação e Adversidade. O Desempenho Escolar dos Alunos de Origem Indiana e Cabo-verdiana no Ensino Básico, Lisbon: Imprensa de Ciências Sociais.

Sebastião, J., (2007/2008), 'Famílias, estratégias educativas e percursos escolares', Sociologia, XVII/ XVIII: 281-306.

Singly, F.D., (2000), 'Penser autrement la jeunesse', Lien Social et Politiques, 43: 9-21.

Taylor, C., (1989), Sources of the Self, Cambridge: Cambridge University Press.

Thévenot, L., (2006), L'action au Pluriel. Sociologie des Régimes d'Engagement, Paris: Editions La Découverte.

Thomson, R., Bell, R., Holland, J., Henderson, S., McGrellis, S. and Sharpe, S., (2002), 'Critical moments: choice, chance and opportunity in young people's narratives of transition to adulthood', Sociology, 36 (2): 335-354.

Threadgold, S. and Nilan, P., (2009), 'Reflexivity of contemporary youth, risk and cultural capital', Current Sociology, 57 (1): 47-68.

Vieira, M.M., (2009), 'A backstage look at student self-determination: the role of parents and schooling options', in Resende, J.M. and Vieira, M.M. (eds), The Crisis of Schooling? Learning, Knowledge and Competencies in Modern Societies, 103-114, Newcastle: Cambridge Scholars Publishing.

Wall, K. (ed.), (2005), Famílias em Portugal, Lisbon: Imprensa de Ciências Sociais.

Warren, C., (2002), 'Qualitative interviewing', in Gubrium, J.F. and Holstein, J.A. (eds), Handbook of Interview Research: Context and Method, 83-101, Thousand Oaks, CA: Sage.

Woodman, D., (2009), 'The mysterious case of the pervasive choice biography: Ulrich Beck, structure/agency, and the middling state of theory in the sociology of youth', Journal of Youth Studies, 12 (3): 243-256.

Woodman, D., (2011), 'Young people and the future: multiple temporal orientations shaped in interaction with significant others', Young, 19 (2): 111-128.

Zanten, A.V., (2009), Choisir son École - Stratégies Familiales et Médiations Locales, Paris: PUF. 